\title{
Characterization of Mycoplasma Strains Isolated from House Musk Shrews (Suncus murinus) and Their Infectivity in Mice and Rats
}

\author{
Kazuo GOTO, Toshio ITOH, Susumu EBUKURO, Naoko KAGIYAMA, \\ and Ryo HARASAWA* \\ Central Institute for Experimental Animals, 1,430 Nogawa, Miyamae-ku, Kawasaki-shi, \\ Kanagawa 216, and *Animal Center for Biomedical Research, Faculty of \\ Medicine, The University of Tokyo, 7-3-1 Hongo, \\ Bunkyo-ku, Tokyo 113, Japan
}

(Received 6 January 1993 /Accepted 19 February 1993)

\begin{abstract}
Five mycoplasma strains isolated from house musk shrews (Suncus murinus) in the Central Institute for Experimental Animals were characterized and compared with three murine mycoplasma strains, Mycoplasma pulmonis m 53, $M$. arthritidis PG6, and $M$. neurolyticum Type A, and with reference strain G3-5 previously isolated from a house musk shrew. These isolates fermented glucose, but did not hydrolyze urea and arginine, passed through membrane filters of $450 \mathrm{~nm}$ pore size, were sensitive to digitonin, and formed minute ( 115 to $231 \mu \mathrm{m}$ in diameter) colonies on agar medium. All the five unclassified house musk shrew mycoplasma strains and strain G3-5 used as a reference constituted a homogeneous group based on (i) their antigenic properties (determined using the metabolism inhibition test), (ii) their polypeptide profiles (determined using sodium dodecyl sulfate-polyacrylamide gel electrophoresis and the Western blotting assay), and (iii) their genomic properties (determined using DNA cleavage pattern analysis), but were quite distinct from the established murine mycoplasmas on the basis of these findings. In a survey of 56 house musk shrews aged 2 to 45 weeks in our colonies, mycoplasmas were isolated from the oral cavities of all animals examined. No gross or microscopic lesions were observed in the five animals from which the mycoplasma strains were isolated. In experimental infection, the mycoplasma was not infective for mice and rats. The results suggest that this group of mycoplasmas is a common inhabitant of house musk shrews. KEY WORDS : characterization, mycoplasma, Suncus murinus
\end{abstract}

Mycoplasmas are widely distributed in nature and have been isolated from many laboratory animal species including nonhuman primates, dogs, mice and rats $[3,8,14,20]$. Moreover, they frequently produce chronic respiratory disease, arthritis and genital tract infections in these animal species. The house musk shrew (Suncus murinus) is a species of insectivore, and has recently attracted attention as a new experimental animal $[9,10,12,18]$, but little information is available on the infectious agents in this animal species. Isolation of mycoplasma from house musk shrew was first reported by Ito et al. in 1988 [11]. However, the organisms from the house musk shrew have not been characterized further, and their rela- tionship with other mycoplasma from rodents has not been established. For this reason, it is necessary to define their characteristics and prevalence of infection in the house musk shrew.

The purposes of the present studies were to examine the properties of the mycoplasmas isolated from house musk shrews, and to investigate the actual state of mycoplasma infection in a house musk shrew colony and their pathogenicity in mice and rats.

\section{Materials and Methods}

Animals. The SUN strain of house musk shrews maintained in four rooms of the Central 
Institute for Experimental Animals (CIEA) as a closed breeding colony was used for these studies. The history of the SUN strain of house musk shrew was previously reported by Mastuzaki et al. [17].

Mycoplasmas. Five mycoplasma strains from house musk shrews were examined. Each strain was isolated from the trachea (G677-2T, G666-16R, G666-16A), the lung (G677-1L) or the prepuce $(\mathrm{G} 677-1 \mathrm{P})$ of three animals aged 12 -16 weeks maintained in different breeding rooms of the facilities. The unidentified isolates were cloned five times by filtration through filters with pore size of $450 \mathrm{~nm}$ to produce pure cultures. Among the reference strains employed as controls in various tests for characterization of the isolates, strain G3-5 isolated from a house musk shrew, Mycoplasma pulmonis $\mathrm{m} 53$ and $M$. neurolyticum Type A were kindly provided by $\mathrm{Dr}$. K. Koshimizu, Department of Veterinary Medicine, Kagoshima University, Japan. M.arthritidis PG6 was generously provided by Dr. M. Nakagawa, Department of Veterinary Science, National Institute of Health, Japan.

Culture media and growth conditions. Media for cultivation of mycoplasmas have been described previously by Cassell et al. [2] . Briefly, the broth medium contained $70 \mathrm{me}$ of PPLO broth (Difco Laboratories, U.S.A.) supplemented with $10 \mathrm{ml}$ of $25 \%$ (wt/vol) yeast extract, $20 \mathrm{~m} \ell$ of heat-inactivated horse serum (GIBCO Laboratories, U.S.A.) , 1 me of 100,000 untits of penicillin $\mathrm{G}, 1 \mathrm{me}$ of $2.5 \%$ thallium acetate, $0.5 \mathrm{~g}$ of glucose and $0.002 \%$ phenol red and $\mathrm{pH}$ was adjusted at 7.8. The agar medium consisted of the same ingredients except that 1.3\% Bacto-agar (Difco) was added, and the glucose and the phenol red were ommitted. Specimens were collected with sterile cotton swabs from each site of the animals, inoculated to the broth and agar media and incubated at $37^{\circ} \mathrm{C}$ in a humid chamber. The broth media were checked for the organisms in the mid-to late-log phase ( $\mathrm{pH} 7.0$ to 7.1).

Preparation of rabbit antisera. For serological tests, hyperimmune rabbit antisera to each mycoplasma were prepared. Each antigen was produced from about $1,000 \mathrm{ml}$ of $24-\mathrm{hr}$ broth culture. The sediment was washed by centrifugation at $8,000 \mathrm{xg}$ for $20 \mathrm{~min}$ with three changes of PBS. The final sediment was resuspended in $20 \mathrm{~m} \boldsymbol{\text { of }} \mathrm{PBS}$ and stored at $-20^{\circ} \mathrm{C}$. Rabbits were injected intravenously with $2 \mathrm{me}$ of the antigen solution six times weekly for 5 consecutive weeks. Sera were dispensed in $2 \mathrm{~m} \ell$ aliquots and stored at $-20^{\circ} \mathrm{C}$ until use.

Characterization of the isolates.

(i) Morphological studies. Mycoplasma colonies grown on the agar medium were examined after 2 days of incubation. The colonies were transferred to slides, stained with Gram's stain and examined by light microscopy

(ii) Reversion studies. Each of the five mycoplasma strains examined was serially subcultured five times in broth media without antimicrobial agents, and each broth subculture was inoculated onto antimicrobial agent-free agar medium and observed for reversion to bacteria [13].

(iii) Filtration studies. Cultures (after $20 \mathrm{hr}$ of incubation) were tested for filtrability with membrane filters (Sartorius, Germany) of different pore sizes 450 and $200 \mathrm{~nm}$ in diameter. Filtrability was determined by color change of the medium after filtration [13].

(iv) Sterol requirement. Growth responses to cholesterol were determined by using a technique that was modified slightly from the recommended indirect method described by Hill et al . [7]. Briefly, the isolates were tested for digitonin susceptibility by using disks containing $0.025 \mathrm{me}$ of a $1.5 \%$ ethanolic solution of digitonin (Wako Pure Chemicals, Osaka, Japan). The width of the zone of growth inhibition was measured in millimeters. (v) Tests for biochemical and biological properties. Glucose fermentation, arginine and urea hydrolysis were assessed by the methods of Mcgarrity et al [15] with some modifications. All procedures were performed with broth or agar cultures that were grown aerobically for 1 to 3 days. Adsorption of erythrocytes was tested with guinea pig, sheep and house musk shrew cells using the method of Manchee et al. [16].

(vi) Metabolism inhibition (MI) test. The test was based on the procedure of Purcell et al. [19] with some modifications. This test was performed using glucose as the substrate and was carried out as follows. In tubes containing $0.5 \mathrm{me}$ each of serial two-fold dilutions of the antiserum, $0.5 \mathrm{~m} \ell$ of broth containing approximately $10^{2}$ to $10^{3}$ color-changing units $(\mathrm{ccu}) / \mathrm{ml}$ 
of the organism was added and then the tubes were incubated at $37^{\circ} \mathrm{C}$. Each antiserum was heated at $60^{\circ} \mathrm{C}$ for 20 min before use and the tests were performed in duplicate.

(vii) Sodium dodecyl sulfate (SDS)-polyacrylamide gel electrophoresis of whole-cell proteins. The centrifuged mycoplasma cells were washed with PBS, resuspended in PBS, and diluted $1: 1$ with a solution containing $2 \%$ SDS, 5\% 2-mercaptoethanol and 20\% glycer$\mathrm{ol}$, and then boiled for $5 \mathrm{~min}$. Electrophoresis was performed on $10 \%$ polyacrylamide gel. Gels were stained with Coomassie brilliant blue R-250 [5].

(viii) Western blotting analysis. Proteins were transferred from the gels to nitrocellulose paper (PALL BIODYNE) by the method of Towbin et al. [21]. Non-specific binding sites were blocked by overnight incubation at $4^{\circ} \mathrm{C}$ in PBS containing $3 \%$ BSA. The rabbit hyperimmune serum prepared against the mycoplasma strain G666-16R was diluted 1:100 in PBS. These antibody preparations were then reacted with the nitrocellulose filter at $37^{\circ} \mathrm{C}$ for $1 \mathrm{hr}$. After being washed three times with PBS, the filter was incubated with horseradish peroxidase-linked protein A diluted 1:1,000 in PBS. After three further washes in PBS, the filter was stained with $0.025 \%$ (wt/vol) diaminobenzidine tetrahydrochloride (Wako Pure Chemicals, Osaka, Japan) in $50 \mathrm{mM}$ Tris-hydrochloride ( $\mathrm{pH} 7.2$ ) containing $0.01 \%$ (vol/vol) hydrogen peroxide.

(ix) Restriction endonuclease analysis. The cell pellets were gently lysed in a solution containing $100 \mathrm{mM}$ EDTA, $0.5 \%$ SDS, and 50 $\mathrm{mM}$ Tris-hydrochloride $(\mathrm{pH} \mathrm{8.0)}$. The cell lysates were treated successively with proteinase $\mathrm{K}$ and then extracted with phenol, phenol-chloroform (1:1), and chloroformisoamyl alcohol $(24: 1)$. Individual DNA preparations were precipitated with two volumes of ethanol in the presence of $0.3 \mathrm{M}$ sodium acetate ( $\mathrm{pH}$ 5.4). Each DNA pellet was dissolved in Tris-EDTA buffer [6]. DNA cleavage by restriction endonuclease was carried out using Hind III purchased from Takara Shuzo Co., Ltd. About $5 \mu \mathrm{g}$ of mycoplasma DNAs was digested with 10 to 15 units of the enzyme. The reaction mixture was incubated at $37^{\circ} \mathrm{C}$ for $2 \mathrm{hr}$ and subjected to $1.0 \%$ agarose gel electrophoresis. After electrophoresis, the gels were stained with ethidium bromide [4] . (x) Survey of mycoplasma in house musk shrews. A total of 56 swab samples of the oral cavity were obtained from 56 house musk shrews, 2 to 45 weeks old, bred and maintained in the CIEA. The isolates were identified by the growth inhibition (GI) test using antiserum against the G666-16 strain. The test was performed by the method of Black [1]. The gross and histopathological lesions were examined in five of the 56 house musk shrews.

(xi) Experimental mycoplasmal inoculation in rats and mice. Six SPF female Jcl:Wistar rats aged 4 weeks and six female SPF Jcl : ICR mice aged 4 weeks were inoculated orally and intranasally. The inoculum contained $3.2 \times 10^{4}$ colony-forming units (cfu) of a mycoplasma strain $(\mathrm{G} 677-2 \mathrm{~T})$. The rats and mice were examined 3 and 7 days after inoculation for the cultivation of mycoplasma using the swabs from their oral cavity.

\section{Results}

Characterization of the isolates.

(i) Morphological studies. Colonies of the five strains grown on agar medium had a fried-egg appearance and measured about 115 to $231 \mu \mathrm{m}$ in diameter. The cells were pleomorphic and gram negative. Most cells were coccoid or cocobacillary.

(ii) Reversion studies. None of these strains tested showed any evidence of reversion to a bacterial form when they were serially subcultured in antimcrobial agent-free agar media.

(iii) Filtration studies. These strains passed through membrane filters of a pore size of 450 $\mathrm{nm}$ but failed to pass through filters of a pore size of $200 \mathrm{~nm}$.

(iv) Sterol requirement. The growth of each of the strains examined was inhibited by $375 \mu \mathrm{g}$ of digitonin when the disk test procedure was used. The inhibition zones surrounded disks with digitonin ranged from 2.4 to $2.5 \mathrm{~mm}$. Colony formation was not inhibited by control disks without digitonin.

(v) Biochemical and biological properties. The biochemical and biological characteristics of these strains were as follows: they fermented glucose, did not hydrolyze arginine and urea, and did not show hemadsorption ability for guinea pig, sheep and house musk shrew erythrocytes. 
Table 1. Serological relationships among the established mycoplasma species and unclassified house musk shrew strains by the MI test

\begin{tabular}{|c|c|c|c|c|c|c|}
\hline \multirow{2}{*}{ Strain } & \multicolumn{6}{|c|}{ Antiserum against } \\
\hline & G666-16R & G677-1L & G3-5 & $\mathrm{m} 53$ & PG6 & Type A \\
\hline \multicolumn{7}{|c|}{ Mycoplasma sp. } \\
\hline G666-16R & 80 & 40 & 80 & - & - & - \\
\hline G677-1L & 80 & 80 & 80 & - & - & - \\
\hline G3-5 & 20 & 20 & 160 & - & - & - \\
\hline \multicolumn{7}{|l|}{ M. pulmonis } \\
\hline $\mathrm{m} 53$ & -a) & - & - & 1280 & - & - \\
\hline \multicolumn{7}{|l|}{ M. arthritidis } \\
\hline PG6 & - & - & - & - & 5120 & - \\
\hline \multicolumn{7}{|c|}{ M. neurolyticum } \\
\hline Type A & - & - & - & - & - & 80 \\
\hline
\end{tabular}

a) No inhibition at serum dilution of $1: 20$

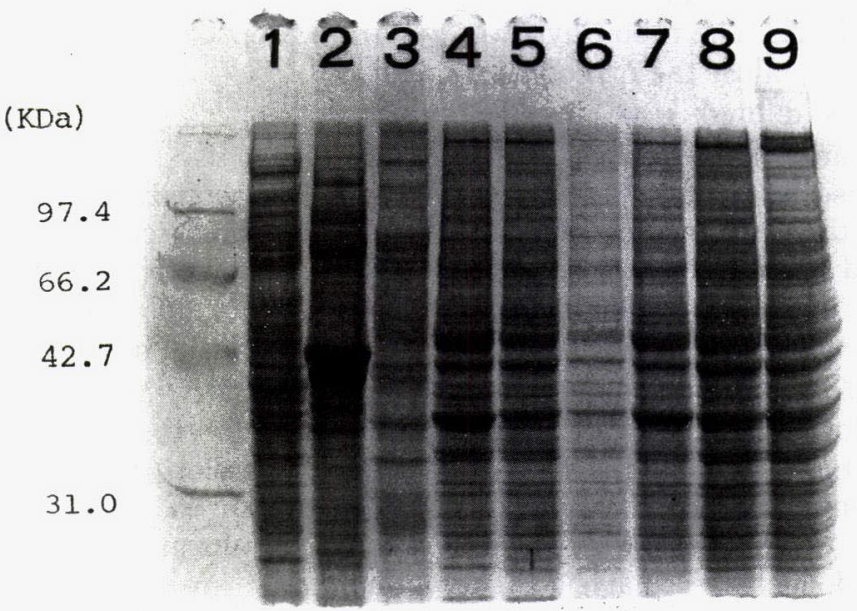

Fig. 1. SDS-polyacrylamide gel electrophoresis of cell protein from rodents and house musk shrew mycoplasma strains. $M$. pulmonis $\mathrm{m} 53$, lane $1 ; M$. arthritidis PG 6 , lane $2 ; M$.neurolyticum type $\mathrm{A}$, lane 3 ; unclassified house musk shrew mycoplasmas G 3-5, lane 4; G 666-16 A, lane 5 ; G 666-16 R, lane 6 ; G 677-1 L, lane 7 ; G 677-2 T, lane 8; G 677-1 $\mathrm{P}$, lane 9 . Molecular mass markers used : rabbit muscle phosphorylase b (97.4 Kdal), bovine serum albumin ( $66.2 \mathrm{Kdal})$, ovalbumin (42.7 Kdal), and carbonic anhydrase $(31.0 \mathrm{Kdal})$.

(vi) MI test. As shown in Table 1, the three house musk shrew mycoplasma strains did not react with the antisera against $M$. pulmonis m53, $M$. arthritidis PG6 and $M$. neurolyticum Type A. Conversely, the antisera prepared against the three house musk shrew mycoplasma strains (strains G3-5, G666-16R and G6771L) reacted with three house musk shrew mycolpasmas but not with the three murine mycoplasma species. (vii) SDS-polyacrylamide gel electrophoresis of whole-cell proteins. As shown in Fig.1, the five strains and strain G3-5 gave similar SDSpolyacrylamide gel electrophoretic protein patterns, and the patterns of house musk shrew mycoplasmas were distinct from those of the previously described three murine mycoplasma species.

(viii) Whole-cell polypeptides of mycoplasmas analyzed by immunoblotting with antiserum 


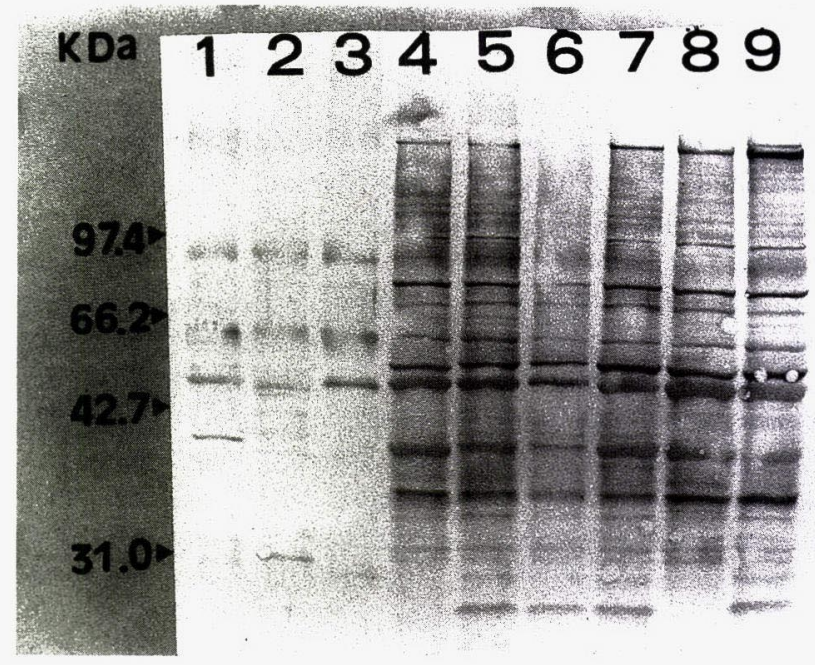

Fig. 2. Immunoblot analysis of whole-cell polypeptides from the same species as shown in Fig. 1, reacting with antibodies against strain $\mathrm{G}$ 677-1 L.

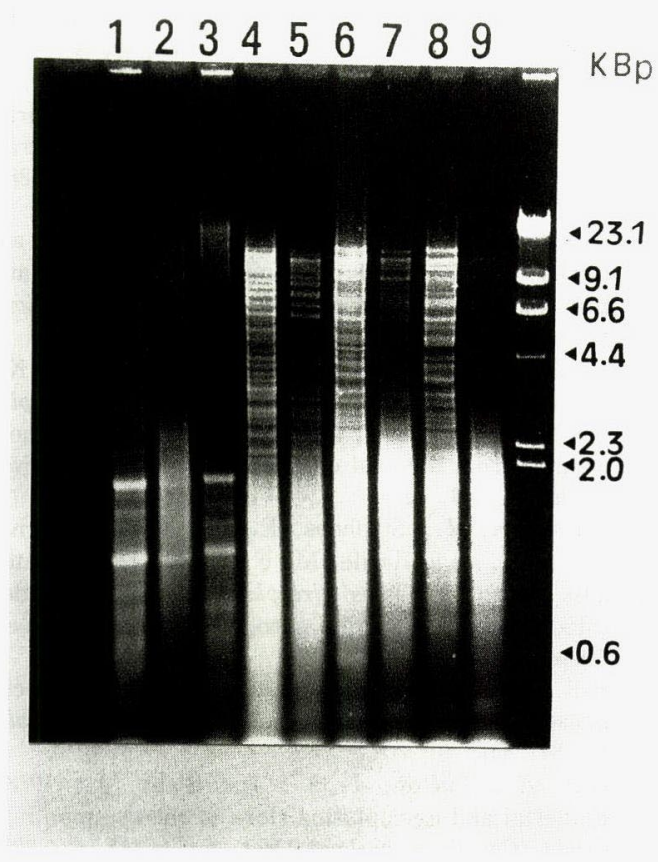

Fig. 3. Cleavage patterns of the chromosomal DNA of mycoplasmas with Hind III. Lane 10 indicates molecular mass references of the phage $\lambda$ DNA cleaved with Hind III. Lanes 1 through 9 are the same as in Fig. 1.

against G677-1L strain are shown in Fig.2. Immunoanalyses of electrophoretic blots in- dicated similar protein profiles for our isolates and strain G3-5. In addition, the strain G677-1 $\mathrm{L}$ antiserum demonstrated only a few crossreactions with murine mycoplasmas.

(ix) Cleavage patterns of chromosomal DNAs from the strains after digestion with Hind III are shown in Fig.3. All house musk shrew mycoplasmas exhibited remarkably similar reaction patterns. On the other hand, the DNA cleavage patterns produced were distinct from those of the murine mycoplasma species.

(x) Epidemiological study. Mycoplasmas were isolated from all oral cavities of the 56 house musk shrews, although no gross lesions were observed in respiratory tracts, joints, or reproductive organs of the house musk shrews in the colony. Histopathologically, no abnormalities were seen in the lungs, tracheas, and spleens of five house musk shrews.

(xi) Experimintal infection in mice and rats. Mice and rats inoculated intranasally with the mycoplasma isolated from the house musk shrew were sacrificed, and oral swabs were taken at 3 or 7 days postinoculation. Neither clinical signs nor gross lesions were observed in the mice and rats, and no mycoplasmas were reisolated from any of the animals.

\section{Discussion}

House musk shrew mycoplasma strains were first isolated in 1988 from various sites of 
experimental and wild house musk shrews by Ito et al. [11] ; two strains of mycoplasma isolated from house musk shrews have been shown to be serologically related to each other but distinct from the nine established mycoplasma species using the GI test [11]. Our findings confirm the previous study [11] and support the notion that our isolates are also serologically related to each other and to a mycoplasma strain isolated previously from a house musk shrew but distinct from the murine mycoplasma species. However, there were some differences in MI titers among the house musk shrew mycoplasma strains when antisera prepared against the house musk shrew strains G666-16 R, G677-1L and G3-5 were used.

The electrophoretic patterns of cell proteins showed that our five isolates and strain G3 -5 have many polypeptides in common. Moreover, the immunoblotting analysis indicated that the polypeptides of similar size specific for house musk shrew mycoplasma strains share common antigenic dererminants. Although the protein patterns among the house musk shrew mycoplasmas were specific, there were a few polypeptides of house musk shrew strains which migrated along with the protein bands of murine mycoplasma strains. Thus, the findings indicate that the five isolates and strain G3-5 have many common, antigenically similar proteins and that they also share a few antigenic determinants with murine mycoplasma polypeptides.

The DNA cleavage patterns revealed close genomic relationships among the house musk shrew mycolpasma strains. Moreover, these strains were genomically distinct and were unrelated to the three murine mycoplasma species.

The combined data from the morphological, biological and serological analyses, the SDS-polyacrylamide gel electrophresis patterns of the cellular proteins and the DNA cleavage patterns indicated that the five house musk shrew mycoplasma strains and strain G3 -5 comprised a homogeneous cluster of related organisms that were quite distinct from the previously described murine mycoplasma species.

The epidemiological study showed that although mycoplasma was isolated from the oral cavity of all 56 house musk shrews, they had no gross lesions in the respiratory tracts, joints or reproductive organs. Previous report [11] also showed that house musk shrews from which mycoplasma was isolated were apparently healthy. The isolation rate of the mycoplasma from the oral cavity was also high (100\%) in comparison with $83 \%$ in the previous report [11]. Moreover, the strains neither produced evidence of disease nor colonized in experimentally inoculated mice and rats.

On the basis of these findings and other biological and serological properties of the organisms, we consider that mycoplasma strains with these characteristics are a peculiar organism present as indigenous microflora in the oral cavity of house musk shrews.

\section{References}

[1] Black, F. T. (1973). Modification of growth inhibition test and its application to human T-mycoplasmas. Appl. Microbiol., 25, 528-533.

[2] Cassell, G.H., Lindsey, J. R., Davis, J. K., Davidson, M. K., Brown, M. B., and Mayo, J. G. (1981). Detection of natural Mycoplasma pulmonis infection in rats and mice by an enzyme linked immunosorbent assay (ELISA). Lab. Anim. Sci., 31, 676-682.

[3] Davis, J. K. and Cassell, G. H. (1982). Murine respiratory mycoplasma in LEW and F344 rats ; Strain difference in lesion severity. Vet. Pathol., 19, 280293.

[4] Harasawa, R., Koshimizu, K., Pan, I.-J., and Barile, M. F. (1985). Genomic and phenotypic analyses of avian ureaplasma strains. Jpn. J. Vet. Sci., 47, 901-909.

[ 5 ] Harasawa, R., Imada, Y., Ito, M., Koshimizu, K., Cassell, G. H., and Barile, M. F. (1990). Ureaplas. ma felinum sp. nov. and Ureaplasma cati sp. nov. isolated from the oral cavities of cats. Int. J. Syst. Bacteriol. , 40, 45-51.

[6] Harasawa, R., Stephens, E. B., Koshimizu, K., Pan, I.-J., and Barile, M. F. (1990). DNA relatedness among established Ureaplasma species and uniden. tified feline and canine serogroups. Int. J. Syst. Bacteriol., 40, 52-55.

[7] Hill, A. C. (1983). Mycoplasma collis, a new species isolated from rats and mice. Int . J. Syst. Bacteriol., 33, 847-851.

[8] Hill, A., Turton, J. A., and Bleby, J. (1978). Bacterial and mycoplasma flora of the common mar. moset (Callithrix jacchus). Vet. Rec., 103, 824-827.

[9] Ishikawa, A. and Namikawa, T. (1991). Postnatal growth pattern of $F_{1}$ hybrids of a cross between two strains of large and small musk shrews, suncus mur inus. Exp. Anim., 40, 223-230.

[10] Ishikawa, A., Hirunagi, K., Oda, S., Namikawa, T., and Tomita T. (1992). Kinky coat, a new autosomal recessive mutation in the musk shrew, Suncus murinus. Exp. Anim., 41, 203-214.

[11] Ito, M., Yamamoto, K., Kotani, H., and Koshimi$z u, K$. (1988). Isolation of mycoplasmas from house 
musk shrews (Suncus murinus). Exp. Anim., 37, 339 -340 .

[12] Kaji, T., Saito, H., Ueno, S., and Matsuki, N. (1990). Comparison of various motion stimuli on motion sickness and acquisition of adaptation in Sun cus murinus. Exp. Anim., 39, 75-79.

[13] Koshimizu, K., Harasawa, R., Pan, I.-J., Kotani, H., Ogata, M., Stephens, E. B., and Barile, M. F. (1987). Ureaplasma gallorale sp. nov. from the oropharynx of chickens. Int . J. Syst. Bacteriol., 37, 333 -338 .

[14] Koshimizu, K. and Ogata, M. (1979). Characterization and differentiation of mycoplasmas of canine origin. Jpn. J. Vet. Sci., 36, 391-406.

[15] Mcgarrity, G. J., Rose, D. L., Kwiatkowski, V., Dion, A. S., Phillips, D. M., and Tully, J. G. (1983). Mycoplasma muris, a new species from laboratory mice. Int. J. Syst. Bacteriol., 33, 350-355.

[16] Manchee, R. J. and Taylor-Robinson, D. (1968). Haemadsorption and haemagglutination by mycoplasmas. J. Gen. Microbiol., 50, 465-478.
[17] Matsuzaki, T., Tanaka, T., Saito, R., Yamanaka, M., Saito, M., and Nomura, T. (1992). Establishment of an outbred strain (Jic:SUN) in the house musk shrew, Suncus murinus. Exp. Anim., 41, 167172.

[18] Ohno, T., Oda, S., Ishikawa, A., and Namikawa, T. (1992) . Red-eyed dilution (rd), a novel coat-color mutant gene in the musk shrew (Suncus murinus, insectivora). Exp. Anim., 41, 173-179.

[19] Purcell, R. H., Taylor-Robinson, D., Wong, D., and Chanock, R. M. (1966). Color test for the mea. surement of antibody to T-strain mycoplasmas. $J$. Bact., 92, 6-12.

[20] Saito, M., Nakayama, K., and Nakagawa, M. (1976) . Localization of Mycoplasma pulmonis in mice. Exp. Anim., 25, 265-272.

[21] Towbin, H., Staehelin, T., and Gordon, J. (1979). Electrophoretic transfer of proteins from polyacrylamide gels to nitrocellulose sheets; Procedure and some application. Proc. Natl. Acad. Sci. USA., 76, 4350-4354 .

\section{スンクスから分離されたマイコプラズマの性状および マウス, ラットへの感染性}

後藤一雄・伊藤豊志雄・江袋進・鍵山直子・原澤 亮*

財団法人実験動物中央研究所

*東京大学医学部附属動物実験施設

財実験動物中央研究所において生産, 維持されてい る実験用スンクスから分離されたマイコプラズマ 5 株の性状を，これまでに報告されているスンクス由来 のマイコプラズマ株 (G 3-5) および觢歯類由来のマイ コプラズマ(M. pulmonis $\mathrm{m} 53, M$. arthritidis PG 6,M.neurolyticum TypeA) と比較した。今回分 離された 5 株はいずれもブドウ糖を分解し，アルギニ ンおよび尿素非分解, 孔径 450-nmの滤過膜通過性, ジキトニン感受性であり，寒天培地上のコロニーの直 径は 115 231 $\mu \mathrm{m}$ であった。また，(i) 代謝阻止試験， (ii) SDS-PAGE, ウェスタンブロッティンクによる夕 ンパク分析，および(iii) 制限醉素によるDNA分析の 結果, これら 5 株はG 3-5 株と同様の結果を示した が, 栔類由来のマイコプラズマとは明確な差異が観 察された。さらに, 我々の施設で生産, 維持されてい る， 2 週㱓から 45 週秢のスンクス 56 匹のマイコプラ ズマ污染調查では全例の口腔からマイコプラズマが 分離された。しかし,これらのうち 5 匹の病理学的検 索では呼吸器等に病変は見出されなかった。また，マ ウス,ラットに対する感染性も認められなかったこと から，本株はスンクスに固有なマイコプラズマである ことが示唆された。 